\title{
Expanding field education: Hope Trust Community Garden
}

\author{
Sandra Heerink, Hope Trust Community Garden, Rangiora, Aotearoa New Zealand \\ Vivienne Sinclair-Phillips, Hope Trust Community Garden, Rangiora, Aotearoa New Zealand \\ Alison Jagger, Aotearoa New Zealand \\ Kathryn Hay, Massey University Aotearoa New Zealand
}

\begin{abstract}
Field education is well known as a defining experience in the personal and professional development of social work students. Authentic, meaningful learning opportunities in the workplace contributes to students becoming socialised to the profession and being able to integrate theoretical learning into their practice. Field education occurs across myriad fields of practice and organisational environments. Community gardens are an emerging field of practice for student placements in Aotearoa New Zealand. This viewpoint reflects on the value of field education in this domain from the perspectives of the field mentor, student and external field educator. The reflections highlight the value of this space for learning and supporting social and environmental justice for clients and communities.
\end{abstract}

KEYWORDS: Field education; community gardens; hope; Christian social work

AOTEAROA

NEW ZEALAND SOCIAL WORK 33(1), 112-115.

CORRESPONDENCE TO: Kathryn Hay

k.s.hay@massey.ac.nz
While community gardens themselves have a long history across the globe, in New Zealand they have only recently emerged as a field of practice for students undertaking social work placements (Corkery, 2004). Community gardens may be developed and sustained by city or district councils, non-government organisations or by local communities themselves. They can fulfil several functions including community building, effective use of unused space, food generation and as a place for social and cultural connection (Corkery, 2004). Consequently, social work students can meet competency and institutional requirements for placements in these environments. This view point offers reflections from a field mentor, student and external field educator on one community garden and its effectiveness as a field of practice for a social work placement.

\section{Manager voice (Sandra)}

The Hope Trust Community Garden was established by the Waimakariri Social Services, Rangiora High School and the Hope Trust in 2010, with the aim to break down social isolation in the Rangiora area. I began as a volunteer in the garden and was then employed by the Waimakariri District Council and then later employed by the Hope Trust. The aim of the gardens widened as the needs of community appeared, and the focus became, not only on growing vegetables, but also on empowering people in other parts of their lives. By meeting people's need for food, clothing and household items a considerable number of people have been attracted to the gardens and strong friendships have been formed. Items are freely distributed, and this has allowed local people to spend their money on the necessities of life, reduce their debts and break their poverty cycle. Initiating a 
fruit and veggie co-op has also helped to improve healthy eating.

Once people's need for food and other necessities are met, they may also become more receptive to receiving support in other aspects of their lives (Sanders \& Munford, 2019). From the outset there has been no stigma in coming to the gardens, no paperwork or fear of dealing with the authorities. We have witnessed people's confidence growing when they are able to dress smartly from our free shop and have haircuts and beauty treatments we can provide in partnership with local services. Consequently, many people have become ready to take the next step to make significant changes in their lives, for example making choices to leave abusive relationships and going from someone who first arrived at the Trust needing a food parcel to someone who has gained full-time employment.

The garden has proved to be a safe space for a wide range of people including those who need to complete their community service. It is a place that welcomes all people for who they are. In 2012, we began to partner with Corrections and youth trusts, for offenders to have a placement in the garden to fulfil their community service hours. These mandated clients are given tasks in the garden and are supervised according to need. The garden is a space that welcomes students from the neighbouring high school along with other social service agencies. Students have their own plot in the garden and assist in the free shop and the fruit and veggie co-op as part of work experience.

Relocated for a season, we were still able to provide a place of friendship and connection, but an exciting new chapter has begun on land purchased by the Baptist Church. This has given us a lovely space for our garden beds, seedling growing and compost piles which provide great opportunities for learning the skills of successful gardening. We are now a thriving community with a free shop, a container for storage, a whānau room and an office. Well-attended daily morning teas, a weekly barbeque and the Hui Wăhine all continue to provide friendship and connection. Our recent partnership with Satisfy Food Rescue provides us with free bread and other food items which are a great help to those who come to the gardens.

The garden is a safe place for those who are marginalised and have had major life events, experiencing many hurts and struggles. Over time, they learn to trust us and are willing to share their pain and receive healing. The garden area now provides a framework for others to mentor and walk life's journey alongside our people and we are now able to offer placements for social work students to bring their much-valued skills. Having a student has allowed many chronic issues facing our garden whānau to be addressed. An example was the student coordinating and facilitating a hui with multiple agencies to collaborate and make a cohesive plan for a whānau who, despite multiple agency involvement, had remained in crisis. The student brought the skills and knowledge to walk alongside this whānau who can now see that their challenges are being addressed and supports are being provided. Another example is a client who had chronic health issues. The student worked with this client to facilitate the journey of gaining the treatment she required and is now on her way to having this resolved. Having a student to support our many garden people with the necessary follow-up required to address their needs has been transformational, empowering our garden people and improving their lives.

I would like to take this opportunity to sincerely thank Rangiora Baptist Church and the Hope Trust for allowing this vision to take place. I have been truly humbled to walk this journey over the years with many people and I have seen them gain enough confidence to take on new responsibilities and to find employment. I give all thanks to God for walking this journey with me. 


\section{Student voice (Vivienne)}

When I first stepped into the Hope Community Trust Community Garden, I had no idea of the incredible field of practice I was entering, or how this grassroots community development would cement my passion for work within the community. As a student on placement, the garden has provided a platform to practise many of the skills and tools I had gathered through my social work degree. I relished the opportunity to practise group work, one-onone client work, advocacy, networking and relationship building with multiple external agencies which then opened pathways of support for the individuals and whannau who enjoy the garden. I also became more aware of Mātauranga Māori as whanaungatanga and connecting with the whenua were part of daily mahi.

As a field of practice, the natural setting helps to eliminate power dynamics and therefore enhance relationship building and therapeutic engagement. The perceived bridge you cross walking into an organisation's office building when seeking support, simply is not there when you enter the garden. It is a place of belonging for anyone who finds their way to it, and many who come here do so for social connection. The garden is the embodiment of social work ethics and core values. Social and environmental justice, human rights and empowerment are tangible within this space. Te Tiriti o Waitangi principles are also embraced through enabling Māori and non-Māori to work alongside one another on the whenua.

The free shop contains everything from clothing, furniture, crockery and household wares, and people are encouraged to take whatever they need. This provides a pathway for people to come back and start to engage, trust and then find the support they may be needing.

The weekly Hui Wāhine is an opportunity for the women in the garden to have their own space to do cooking classes, craft or learn skills such as self-care techniques or assertive communication. I facilitated the latter after requests by the garden wāhine. Tino rangatiratanga is alive in action within the community garden space.

The beautiful garden office with a mural gifted from a local Ngāi Tahu artist, Mandy Palmer, sets the scene for tangible social justice and individual empowerment work to take place alongside the many garden tāngata. Every Friday there is a BBQ which is free for all with kai coming from the Hope Trust food bank and local food rescue organisations. This provides the opportunity to sit and share kai and conversation at the end of each week before the garden closes up until the following Tuesday.

Nettle (2014) discusses community gardens as platforms that allow the enactment of social change, and the transformations that take place in the people within the garden space mirrors the ever-changing garden they are working within. If you are lucky enough to have a cuppa and some kai with the garden whānau you will soon understand you are in a very special place. It was an honour to work alongside the tāngata who make up the garden whānau, guided and always safe within intentional clear boundaries. My field mentor's genuine heartfelt care for her garden whānau and passion to create and hold steadfast a safe space where fundamental needs are met is the foundation of all that occurs in the garden. If you are fortunate enough to be a student on placement in the Hope Community Garden, your professional practice will be forever enhanced by the experience.

\section{External field educator voice (Alison)}

It has been a great pleasure to provide external supervision to students at The Hope Community Trust in Rangiora. It is always great to see the amazing work they achieve with the care and support 
of the staff there, alongside my guidance and experience. In my supervision sessions I offer accountability, mentoring, and an opportunity to discuss skills, explore best practice and identify any gaps in social work competencies. I work alongside supporting individual needs through creating goals and a professional development plan. I create a safe space to reflect on practice and ensure the supervisee has all the supports they need to carry out their role in a confident and competent way.

Having been a student at the Hope Trust myself many years ago, I have a good understanding of its vision, values and aims for the community going forward into the future, which align with my own. Community development is at the heart of The Hope Trust vision which looks for ways to respond, fill gaps and support the community where it can. The community garden is one such initiative. Students have been committed to the mahi and have added considerable value through creating new initiatives and projects where they saw gaps. Some of these are still operating. An example of this is the We Welcome Women support group for socially isolated women in the local community to come together and make new friends, to learn from guest speakers and do fun activities like clothes swaps and pamper mornings.

The practice in the community garden aligns with the Aotearoa New Zealand social work Code of Ethics (ANZASW, 2019) and Social Workers Registration Board Code of Conduct (SWRB). The placement offers grassroots social work to local people who would benefit from some help and support. Further, it is a good place for student placement as the organisation's staff can challenge and grow the students in a Christian environment whilst caring for the local community. Practising from a holistic perspective, with a focus on health and safety, best practice and selfcare, there is a synergy between the work in the garden and the externally provided supervision.

\section{Conclusion}

The Joint Amplification of The Global Definition for the Asia Pacific Region (Asia Pacific Association for Social Work Education, 2017) emphasises the importance of encouraging sustainable social work and social development practices and the Aotearoa New Zealand Association of Social Workers (ANZASW) Code of Ethics now incorporates environmental well-being, sustainability and justice (ANZASW, 2019). Community gardens, albeit in a small, but important, way contribute to meeting these aspirations for local communities. Student engagement through placements in these contexts enables students to recognise and be part of community development, sustainable social work practices and meaningful and authentic learning experiences.

\section{References}

Aotearoa New Zealand Association of Social Workers (ANZASW). (2019). Code of ethics (3rd rev) Author. https://anzasw.nz/anzasw-publications-2/

Asia Pacific Association for Social Work Education. (2016). Joint amplification of the global definition on social work profession in Asia and Pacific. http://www.apaswe. com/index.php/news-event/159-check-it-out-apasweno-12-2015-2017

Corkery, L. (2004). Community gardens as a platform for education for sustainability. Australian Journal of Environmental Education, 20(1), 69-75.

Nettle, C. (2014). Community gardening as social action. Ashgate Publishing.

Sanders, J., \& Munford, R. (2019). PARTH practices and better outcomes: Creating "lucky" encounters between social workers and vulnerable youth. In R. Munford \& K. O'Donoghue (Eds.), New theories for social work practice: Ethical practice for working with individuals, families and communities (pp. 27-43). Jessica Kingsley Publishers.

Social Workers Registration Board. (n.d.). Code of conduct. Author. https://swrb.govt.nz/public-and-employers/codeof-conduct/ 